\title{
Improving Dental Students Fine Motor Skills by Visualization and Mental Imagery: A Pilot Randomized Clinical Trial
}

\author{
Mejora de las Habilidades Motoras Finas de los Estudiantes de Odontología \\ Mediante Visualización e Imaginería: Ensayo Clínico Aleatorizado Piloto
}

Jorge Jofré; Jeannette Fuentes; Yuri Conrady; Manuel Michel; Paula Quintana \& Claudia Asenjo-Lobos

JOFRÉ, J.; FUENTES, J.; CONRADY, Y.; MICHEL, M.; QUINTANA, P. \& ASENJO-LOBOS, C. Improving dental students fine motor skills by visualization and mental imagery: A pilot randomized clinical trial. Int. J. Odontostomat., 13(1):69-74, 2019.

ABSTRACT: Clinical motor skills are essential to train dental students. There is evidence that imagery serves to acquire and improve motor skills, since imagining an action, activates the same neural areas as when this is physically performed. The aim of this pilot randomized clinical trial was to examine the feasibility of tridimensional visualization associated with mental imagery on the development of fine motor skills of dental students compared to conventional training. Seventeen dental students without previous preclinical experiences, between 18-25 years old were recruited. After giving a theoretical lecture on the inlay preparation, participants were randomly allocated in two groups. The Experimental Group ( $\mathrm{N}=9$ ) performed daily 30 minutes of "mental practice" after visualizing a video showing the execution of an ideal inlay preparation alternating it with black screen periods to facilitate the imagery. The Control Group $(\mathrm{N}=8)$ performed a 30 minutes "hands on practice" daily of the same preparation. On the fifth day, both groups carried out an inlay preparation physically, which was scanned and overlapped to the virtual preparation to assess accuracy. The execution time and accuracy of the preparation performed with regard to an ideal preparation were compared between groups. The learning style and fine motor skills at baseline were similar in all participants $(P>0.001)$. No statistically significant differences were found between the groups in terms of accuracy. The time of execution in the experimental group was significantly lower than the control group. This pilot study showed that visualization associated to mental imagery could develop fine motor skills in dental students, requiring less execution time than physical practice.

KEY WORDS: three-dimensional imaging, pilot projects, dental education, simulation training, clinical trial, dentistry.

\section{INTRODUCTION}

Fine motor skills development is one of the key factors for training dental students. Manual dexterity can be improved by means of practical training to develop a good skills level even in people with poor manual abilities (Giuliani et al., 2007). A time-restricted curricula and more demanding surgical techniques represent a challenge for teachers who want their students to achieve adequate motor skills in a short period of time (Perry et al., 2015). Recent technology associated to simulation and games (e.g. virtual reality simulators, haptic technology) that incorporates 3D images and tools for immediate feedback, has allowed students to be able to practice in their own time (Sullivan et al., 2015). These tools have also shown a positive effect on their performance (de Boer et al., 2016). However, some negative aspects have been reported such as high initial costs, training personnel and lack of simulation programs (Perry et al.).

Imagery practice is defined as repetitive cognitive rehearsal of a physical action in the absence of any voluntary muscular movement (Hall, 2002; Page \& Peters, 2014). Bathalon et al. (2005) have added physical movements to enhance the effects of the mental practice.

\footnotetext{
${ }^{1}$ Center for Advanced Prosthodontics and Implant Dentistry, School of Dentistry, Universidad de Concepción, Chile.

This work was supported by The Academic Innovation Fund (FIAC2 UCO 1120) of the Chilean government.
} 
Several studies have shown that imagery is useful to acquire and improve motor skills, since imagining an action, activates the same neural areas as when this is performed physically (Sobierajewicz et al., 2016). A systematic review (Rao et al., 2015) of nine studies evaluated the role of mental training in the acquisition of surgical technical skills and more than half of these trials showed beneficial effects of mental training. It was not possible to analyze other outcomes due to sample heterogeneity. Another systematic review (Schuster et al., 2011), evaluated the effect of motor imagery on five different disciplines, including medicine, showing a positive effect of mental training in interventions with motor-focused or strength-focused tasks in all disciplines.

It is argued that $3 \mathrm{D}$ vision may be relevant in dentistry training because students require good perceptual, spatial and visual skills to estimate distances, sizes and shapes (Dimitrijevic et al., 2011). The fact of combining $3 \mathrm{D}$ vision and imagery could improve the acquisition of fine motor skills in dental students with a simple and low cost implementation, allowing an autonomous learning outside the classroom. In the current study we tested the hypothesis that dental student training by means of tridimensional visualization associated with mental imagery is feasible on the development of fine motor skills of dental students when compared with conventional training.

\section{MATERIAL AND METHOD}

This single blind randomized clinical trial was carried-out in the Center for Advanced Prosthodontics and Implant Dentistry, Dental School, University of Concepcion, Chile. It was developed following the guidelines of the Declaration of Helsinki and approved by the Institutional Ethics Committee. A written informed consent was obtained from all participants once the study was fully explained.
Seventeen dental students without previous preclinical experiences, between 18-25 years old were recruited in December 2014. Students taking drugs affecting the central nervous system were excluded.

At baseline, the learning style (Learning Style Inventory) (Kolb \& Kolb, 2005) and fine motor skills [Perceptual Ability Test PAT (Gray \& Deem, 2002)] of all participants were assessed. Participants were given instructions to follow regarding their sleeping times and eating habits. Compliance with these instructions was assessed by means of a daily questionnaire. An inlay preparation theoretical lecture was given to the complete cohort using digital images of an ideal inlay preparation on a scanned 3.7 artificial tooth (MOM, Marilia, Brazil).

After that, participants were randomly allocated to two groups following a simple randomization procedure (computer-generated list of random numbers, centralized). Sealed opaque envelopes numbered were opened sequentially by the recruiting clinician. Nine participants were allocated to Experimental Group (EG) and eight to Control Group (CG) (Fig. 1).

Daily, each student of the EG group performed a 30 minutes "mental practice" after visualizing and listening to a video showing the execution of an ideal inlay preparation on a $3 D$ digital model using 3D glasses (CINEMIZER Plus, Carl Zeiss, Jena, Germany), alternating it with black screen periods, keeping the audio (dental drill sound during the tooth preparation) to facilitate the imagery of this procedure. At the same time, each student of the CG group performed a conventional training, 30 minutes "hands on practice" daily of the same inlay preparation on an artificial 3.7 teeth (MOM, Marilia, Brazil) mounted in a manikin, without water.

On the fifth day, both groups carried out a physically inlay preparation on an artificial 3.7 teeth mounted in a manikin.

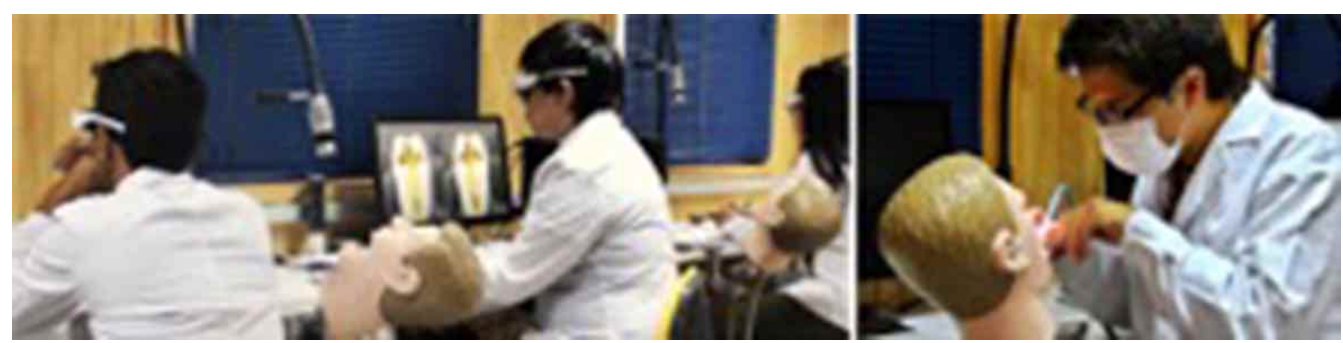

Fig. 1. a) Experimental Group: mental practice (visualization + imagery) and b) Control Group: Hands-On physical practice. 
Assessment. The primary outcome was the accuracy percentage of the preparation performed physically by students regarding the ideal. Results were compared between groups. Additional analysis was carried out comparing the time required to perform each preparation between groups.

Accuracy percentage of the preparation. An unmodified standardized artificial 3.7 tooth was scanned with InEos Blue scanner (Sirona, Beinsheim, Germany) and the ideal inlay preparation was virtually designed with Rhinoceros 3D (Robert McNeel \& Associates, Seattle, WA, USA).

This ideal three-dimensional preparation was used in the theoretical lecture and to compare it with each physical preparation performed by the students.

Using Geomagic ${ }^{\circledR}$ Control (3D Systems, Rock Hill, SC) the scanned dental preparation performed by students was overlapped and aligned to the virtual ideal inlay preparation on the fifth training day. See the screenshot image from metrology software in Figure 2.
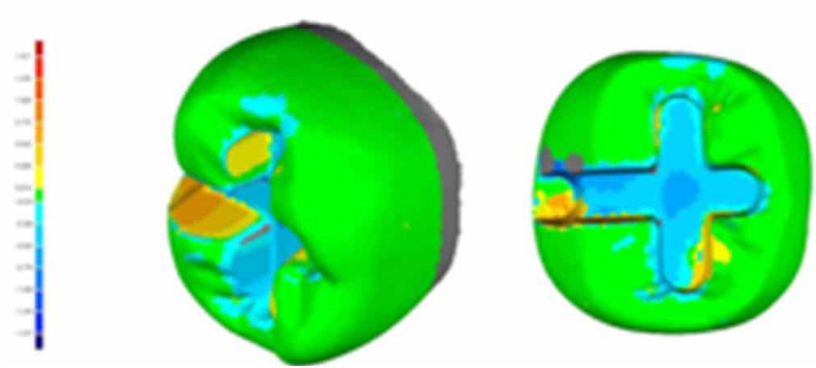

Fig. 2. Screenshot image from metrology software, showing 3D deviation between the scanned student tooth preparations overlapped with the ideal preparation. High accuracy is shown in the center of the color scale in a range of +0.3 to $-0.3 \mathrm{~mm}$ (cyan/green/yellow), medium range between \pm 0.31 to \pm 1.0 $\mathrm{mm}$ (light blue/ orange gradient) and low accuracy \pm 1.1 to $\pm 1.5 \mathrm{~mm}$ (blue/red gradient).

Once samples were aligned, the points corresponding to the prepared area to be assessed were isolated. Within this area, the closest points to the surface of the ideal preparation (deviations range from +0.3 to $-0.3 \mathrm{~mm}$ ) were used to calculate the percentage of accuracy.

Time. Time required to perform each preparation was recorded by using a digital watch.

Sample size. It was considered a sample size of 12 participants per group based on Julious rule of thumb for a pilot study (Julious, 2005).
Statistical methods. Data were analyzed using SPSS version 20.0 (SPSS Inc., Chicago, IL, USA). The students' characteristics were compared using Chisquare or Fisher's exact test (categorical variables) and Mann-Whitney test (continuous variables). The accuracy percentage of the student preparation regarding the ideal preparation between groups was analyzed with the non-parametric Mann-Whitney test for two independent samples. The same test was used to compare the average time between groups. A statistically significant difference was considered if $\mathrm{P} \leq$ 0.05 . An independent assessor blinded to the interventions, carried-out the statistical data analysis.

\section{RESULTS}

A total of 17 participants were randomized into study groups (Fig. 3). The baseline characteristics in both groups were similar $(P>0.001)$ (Table I). The accuracy percentage, regarding the ideal preparation of the Experimental Group ( $\mathrm{N}=9,71.6 \pm 9.9 \%$ ), was not statistically significantly different compared to the accuracy of the Control Group ( $\mathrm{N}=8,77.7 \pm 7.8 \%) \mathrm{P}=$ 0.184 (Fig. 4). The preparation execution time in the Experimental Group was significantly lower $(\mathrm{N}=9,4.3$ $\pm 1.2 \mathrm{~min}$ ) than the time required by the Control Group $(\mathrm{N}=8,8.0 \pm 2.3 \mathrm{~min}) ; \mathrm{P}=0.001$ (Fig. 5).

\section{DISCUSSION}

Mental training by imagery has shown to be effective in athletes, musicians and during rehabilitation to develop motor skills (Lotze \& Halsband, 2006).

For mental imagery to be effective, the learner should be familiarized with the task before the imagery session (Rogers, 2006). In this study, 3D visualization of an ideal tooth preparation was repeated to facilitate mental imagery. Students, after 5 days of mental training using visualization and imagery showed similar results on dental preparation than students trained with motor training as conventional method, suggesting that visualization associated to mental imagery could be as effective as conventional hands-on training. Moreover, execution times were reduced almost half of the time in the Experimental Group. However, further studies should include a retention test to determine the effect of visualization associated to imagery on longterm clinical performance. 


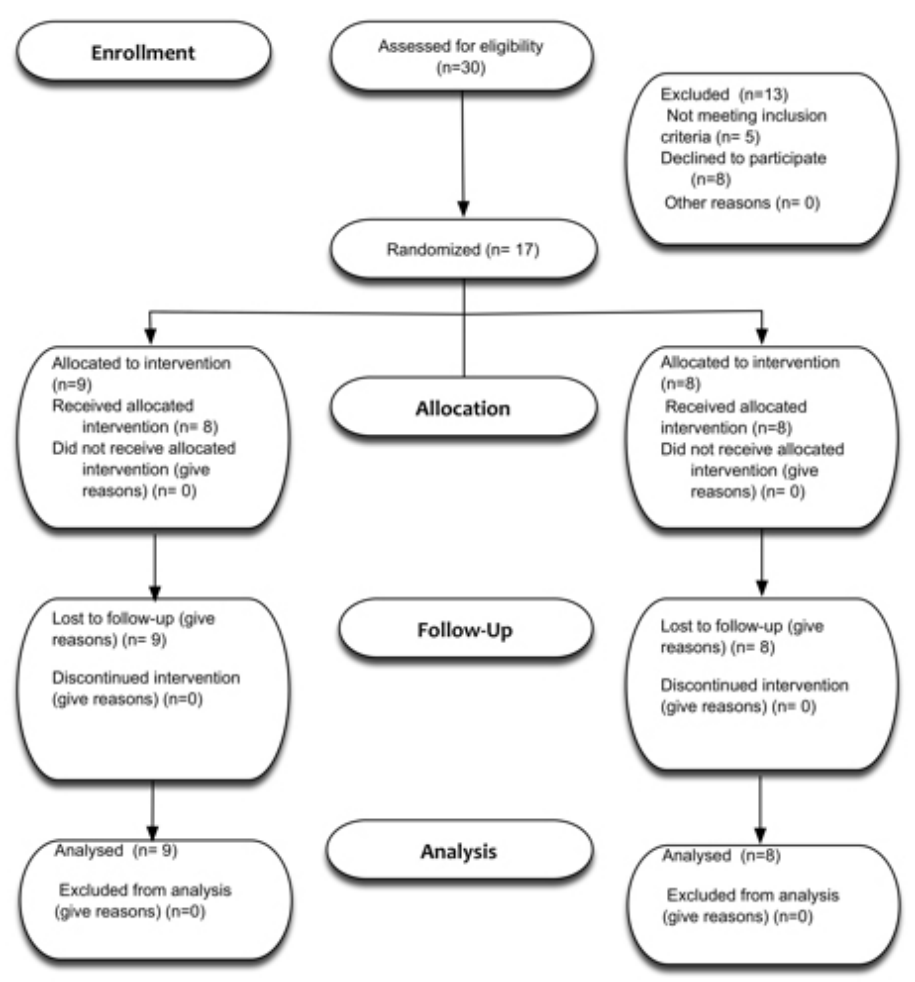

Fig. 3. Flow diagram of a pilot randomized clinical trial of tridimensional visualization associated with mental imagery vs. conventional training on the development of fine motor skills of dental students.

Table I. Participants characteristics.

\begin{tabular}{|c|c|c|}
\hline & $\begin{array}{c}\text { Visualization + } \\
\text { Imagery } \\
N=9\end{array}$ & $\begin{array}{c}\text { Conventional } \\
\text { Training } \\
N=8\end{array}$ \\
\hline \multicolumn{3}{|l|}{ Age } \\
\hline $18-19$ & 7 & 7 \\
\hline $20-21$ & 2 & 1 \\
\hline \multicolumn{3}{|l|}{ Sex } \\
\hline Female & 4 & 4 \\
\hline Male & 5 & 4 \\
\hline \multicolumn{3}{|l|}{ Household Incomes (USD) } \\
\hline$\leq 320-620$ & 3 & 4 \\
\hline$>620-1,250$ & 3 & 2 \\
\hline$>1,250$ & 3 & 2 \\
\hline \multicolumn{3}{|l|}{ Educational Level } \\
\hline Private & 1 & 0 \\
\hline Subsidized & 7 & 6 \\
\hline Traditional & 1 & 2 \\
\hline \multicolumn{3}{|l|}{ Phenotype } \\
\hline Right handed & 8 & 8 \\
\hline Left handed & 0 & 0 \\
\hline Ambid extrous & 1 & 0 \\
\hline $\mathrm{CNS}^{*}$ Diseases & 0 & 0 \\
\hline $\mathrm{CNS}^{*}$ Medic ines & 0 & 0 \\
\hline \multicolumn{3}{|l|}{ Learning Style (Kolb) } \\
\hline Accommodator & 3 & 1 \\
\hline Divergers & 0 & 1 \\
\hline Convergers & 0 & 1 \\
\hline Assimilators & 5 & 3 \\
\hline Perceptual Ability Test (PAT) & $18 \pm 1.4$ & $17.8 \pm 1.3$ \\
\hline
\end{tabular}

${ }^{*}$ Central Nervous System.

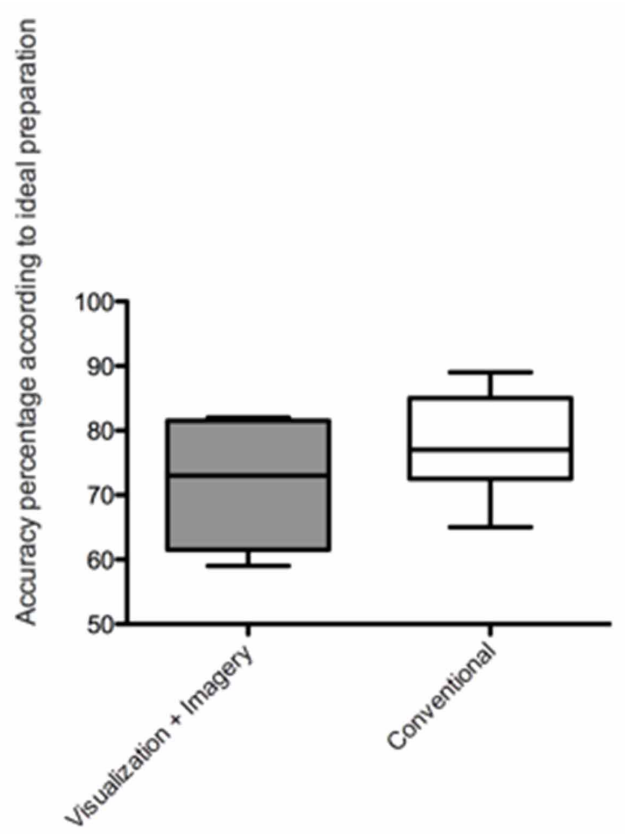

Fig. 4. Comparison between groups, using the non-parametric Mann-Whitney test, showed no significant statistical differences regarding the accuracy percentage of tooth preparation related to the ideal.

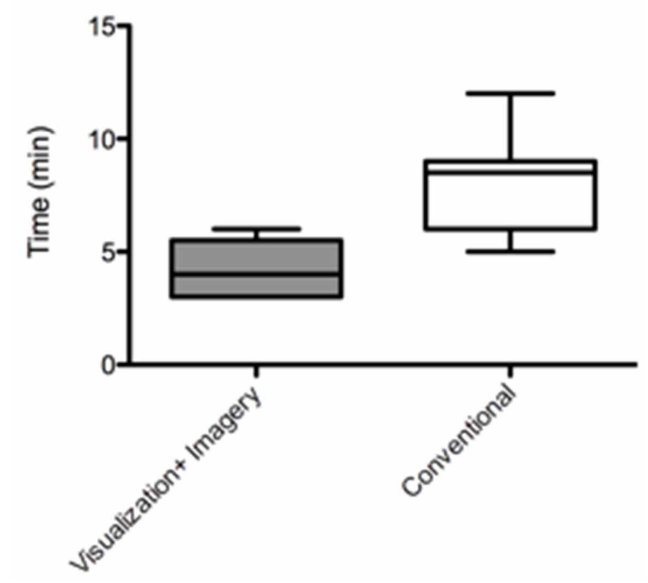

Fig. 5. The Mann-Whitney test showed a significant statistical difference, regarding the tooth preparation execution time, between the Experimental Group compared with the Control Group. 
Also, it is argued that mental training combined with physical training could be more effective than performing only one of this training methods (Lim et al., 2016). Further research should evaluate the effect of simultaneous mental and physical training on this area.

This results agree with a previous study which postulates that mental imagery may be equivalent to physical practice (Sanders et al., 2004). Regarding to the time-restricted curricula, this methodology could allow students to learn at any time and any place.

The development of fine motor skills in dental students by means of visualization associated to mental imagery could reduce preclinical times, favoring an autonomous training outside the classroom with lower cost of implementation since no physical environment is required.

This pilot study provides preliminary evidence on the efficacy of visualization and mental imagery on motor skill training in dentistry. The study design and methodology is feasible to be applied in a large and long-term international multicenter trial.

\section{CONCLUSION}

This pilot study showed a trend that visualization associated to mental imagery could be as effective as the conventional physical practice to perform teeth preparations in preclinical dental students. The time required to prepare a tooth by the mental training group was half of the time required by the conventional group.

The proposed study design provides adequate information to assist the preparation of larger scale trial.

\section{ACKNOWLEDGMENTS}

This work was supported by The Academic Innovation Fund (FIAC2 UCO 1120) of the Chilean government.

Authors thank to lan Kiel and Frane Zilic from 3DInnovation Lab, University of Concepcion, for their work on processing and analyzing samples.
JOFRÉ, J.; FUENTES, J.; CONRADY, Y.; MICHEL, M.; QUINTANA, P. \& ASENJO-LOBOS, C. Mejora de las habilidades motoras finas de los estudiantes de odontología mediante visualización e imaginería: ensayo clínico aleatorizado piloto. Int. J. Odontostomat., 13(1):69-74, 2019.

RESUMEN: Las habilidades motoras clínicas son esenciales para entrenar a los estudiantes de odontología. Existe evidencia que la imaginería sirve para adquirir y mejorar las habilidades motoras, ya que al imaginar una acción, se activan las mismas áreas neuronales que cuando la acción se realiza físicamente. El objetivo de este ensayo clínico aleatorizado piloto fue examinar la factibilidad del uso de visualización tridimensional asociada con imaginería para el desarrollo de las habilidades motoras finas en estudiantes de odontología comparado con el entrenamiento convencional. Se reclutaron diecisiete estudiantes de odontología, entre 18-25 años de edad, sin experiencias preclínicas previas. Después de recibir una clase teórica sobre la preparación de una incrustación, los participantes fueron asignados aleatoriamente a dos grupos. El grupo experimental $(N=9)$ realizó diariamente 30 minutos de "práctica mental" después de visualizar un video que muestra la ejecución de una preparación de incrustación ideal alternando con períodos de pantalla negra para facilitar la imaginación. El grupo de control $(\mathrm{N}=8)$ realizó una práctica diaria de 30 minutos de la misma preparación. El quinto día, ambos grupos llevaron a cabo físicamente una preparación de incrustación, que fue escaneada y esta imagen se superpuso a la preparación virtual ideal para evaluar la precisión. El tiempo de ejecución y la precisión de la preparación realizada con respecto a una preparación ideal se compararon entre ambos grupos. El estilo de aprendizaje y las habilidades motoras finas al inicio del estudio fueron similares en todos los participantes $(P>0,001)$. No se encontraron diferencias estadísticamente significativas entre los grupos en términos de precisión. El tiempo de ejecución en el grupo experimental fue significativamente menor que en el grupo control. Este estudio piloto mostró que la visualización asociada a imaginería podría desarrollar habilidades motoras finas en estudiantes de odontología, requiriendo menos tiempo de ejecución que la práctica física.

PALABRAS CLAVE: imagenes tridimensionales, estudio piloto, educación dental, entrenamiento preclínico, ensayo clínico, odontología.

\section{REFERENCES}

Bathalon, S.; Dorion, D; Darveau, S. \& Martin, M. Cognitive skills analysis, kinesiology, and mental imagery in the acquisition of surgical skills. J. Otolaryngol., 34(5):328-32, 2005.

de Boer, I. R.; Wesselink, P. R. \& Vervoorn, J. M. Student performance and appreciation using $3 D$ vs. $2 D$ vision in a virtual learning environment. Eur. J. Dent. Educ., 20(3):142-7, 2016. 
JOFRÉ, J.; FUENTES, J.; CONRADY, Y.; MICHEL, M.; QUINTANA, P. \& ASENJO-LOBOS, C. Improving dental students fine motor skills by visualization and mental imagery: A pilot randomized clinical trial. Int. J. Odontostomat., 13(1):69-74, 2019.

Dimitrijevic, T.; Kahler, B.; Evans, G.; Collins, M. \& Moule, A. Depth and distance perception of dentists and dental students. Oper. Dent., 36(5):467-77, 2011.

Giuliani, M.; Lajolo, C.; Clemente, L.; Querqui, A.; Viotti, R.; Boari, A. \& Miani, C. M. Is manual dexterity essential in the selection of dental students? Br. Dent. J., 203(3):149-55, 2007.

Gray, S. A. \& Deem, L. P. Predicting student performance in preclinical technique courses using the theory of ability determinants of skilled performance. J. Dent. Educ., 66(6):721-7, 2002.

Hall, J. C. Imagery practice and the development of surgical skills. Am. J. Surg., 184(5):465-70, 2002.

Julious, S. A. Sample size of 12 per group rule of thumb for a pilot study. Pharm. Stat., 4(4):287-91, 2005.

Kolb, A. Y. \& Kolb, D. A. Learning styles and learning spaces: enhancing experiential learning in higher education. Acad. Manag. Learn. Educ., 4(2):193-212, 2005.

Lim, G.; Krohner, R. G.; Metro, D. G.; Rosario, B. L.; Jeong, J. H. \& Sakai, T. Low-fidelity haptic simulation versus mental imagery training for epidural anesthesia technical achievement in novice anesthesiology residents: a randomized comparative study. Anesth. Analg., 122(5):1516-23, 2016.

Lotze, M. \& Halsband, U. Motor imagery. J. Physiol. Paris, 99(46):386-95, 2006

Page, S. J. \& Peters, H. Mental practice: applying motor PRACTICE and neuroplasticity principles to increase upper extremity function. Stroke, 45(11):3454-60, 2014.

Perry, S.; Bridges, S. M. \& Burrow, M. F. A review of the use of simulation in dental education. Simul. Healthc., 10(1):31-7, 2015.

Rao, A.; Tait, I. \& Alijani, A. Systematic review and meta-analysis of the role of mental training in the acquisition of technical skills in surgery. Am. J. Surg., 210(3):545-53, 2015.

Rogers, R. G. Mental practice and acquisition of motor skills: examples from sports training and surgical education. Obstet. Gynecol. Clin. North Am., 33(2):297-304, 2006.

Sanders, C. W.; Sadoski, M.; Bramson, R.; Wiprud, R. \& Van Walsum, $K$. Comparing the effects of physical practice and mental imagery rehearsal on learning basic surgical skills by medical students. Am. J. Obstet. Gynecol., 191(5):1811-4, 2004.

Schuster, C.; Hilfiker, R.; Amft, O.; Scheidhauer, A.; Andrews, B.; Butler, J.; Kischka, U. \& Ettlin, T. Best practice for motor imagery: a systematic literature review on motor imagery training elements in five different disciplines. BMC Med., 9:75, 2011.

Sobierajewicz, J.; Szarkiewicz, S.; Przekoracka-Krawczyk, A.; Jas'kowski, W. \& van der Lubbe, R. To what extent can motor imagery replace motor execution while learning a fine motor skill? Adv. Cogn. Psychol., 12(4):179-92, 2016.

Sullivan, S. A.; Anderson, B. M. \& Pugh, C. M. Development of technical skills: education, simulation, and maintenance of certification. J. Craniofac. Surg., 26(8):2270-4, 2015.
Corresponding author:

Dr. Jorge Jofré

Center for Advanced Prosthodontics and Implant Dentistry

Universidad de Concepción

Victoria 232, Barrio Universitario

Concepción

CHILE

Email: jjofre@udec.cl or jjofre@crai.cl.

Received: 30-07-2018

Accepted: 18-10-2018 